\title{
PENGEMBANGAN GAME GAMELAN SELONDING BALI BERBASIS VIRTUAL REALITY
}

\author{
Putu Ari Indrawan Dewantara ${ }^{1}$, Gede Aditra Pradnyana ${ }^{2}$, I Made Agus Wirawan ${ }^{3}$ \\ 1,2,3 Jurusan Pendidikan Teknik Informatika, Universitas Pendidikan Ganesha \\ Singaraja, Indonesia
}

e-mail: ariindrawan7@gmail.com, gede.aditra@undiksha.ac.id, imade.aguswirawan@undiksha.ac.id

\begin{abstract}
Abstrak
Gamelan adalah sebuah orkestra yang terdiri dari bermacam-macam instrumen yang terbuat dari batu, kayu, bambu, besi, perunggu, kulit, dawai, dan lain-lain dengan menggunakan laras pelog dan slendro. Salah satu cara agar generasi muda tertarik melestarikan gamelan selonding adalah dibuatkan sebuah game berbasis virtual reality, di mana penggunanya dapat berinteraksi dengan dunia virtual akan membuat masyarakat antusias untuk mencoba memainkan gamelan selonding tersebut. Pengembangan Game Gamelan Selonding Berbasis Virtual Reality ini memiliki fitur bermain bebas dan bermain dengan lagu.Pengembangan produk dengan model ini dapat menghasilkan produk yang baik, karena pada setiap fase yang dilalui dapat melakukan evaluasi. Pengujian untuk mengetahui respon masyarakat setelah menggunakan Game Gamelan Selonding Berbasis Virtual Reality dilakukan dengan metode angket dan memiliki hasil dengan persentase ratarata sebesar $88.5 \%$ yang artinya aplikasi masuk kategori sangat baik.
\end{abstract}

Kata kunci: Game, Virtual Reality, Gamelan Selonding

\begin{abstract}
Gamelan is an orchestra consisting of various instruments made of stone, wood, bamboo, iron, bronze, leather, strings, etc. by using pelog and slendro barrel. One way for young people to be interested in preserving the selonding gamelan is to create a virtual realitybased game, where users can interact with the virtual world to make people enthusiastic about trying to play the selonding gamelan. Selonding Gamelan Game Development Based on Virtual Reality features free play and play with songs. Product development with this model can produce good products, because at each phase that is passed can evaluate. Testing to find out the response of the community after using the Selonding Gamelan Game Based on Virtual Reality was conducted by questionnaire method and had results with an average percentage of $88.5 \%$ which means the application is in a very good category.
\end{abstract}

Keywords : Games, Virtual Reality, Gamelan Selonding

\section{PENDAHULUAN}

Bali merupakan salah satu pulau di Indonesia yang terkenal akan ragam keseniannya. Kesenian sebagai suatu bentuk ekspresi, sebagai perwujudan atau simbolisasi dari perasaan dan pikiran manusia, tercakup pula pandanganpandangan atau nilai-nilai yang dianutnya [1]. Salah satu jenis kesenian Bali yang berkembang adalah seni gamelan. Gamelan adalah sebuah orkestra yang terdiri dari bermacam-macam instrumen yang terbuat dari batu, kayu, bambu, besi, perunggu, kulit, dawai, dan lain-lain dengan menggunakan laras pelog dan slendro [2]. Selonding merupakan gamelan Bali yang usianya lebih tua dari gamelan-gamelan yang kini populer dipakai dalam kesenian maupun dalam upacara adat dan agama. Sejalan dengan perkembangannya, gamelan selonding tidak hanya dimainkan dalam konteks upacara ritual, melainkan juga dipakai sebagai kepentingan profan (dalam arti sebagai bagian dalam aktivitas penciptaan musik 
kreasi baru bahkan kontemporer) dan media kreativitas dalam membuat komposisi. Dengan adanya gamelan selonding yang bisa digunakan untuk pertunjukan, maka para generasi muda dapat lebih mudah mempelajari gamelan selonding dan keberadaannya di setiap sanggar di Bali akan sangat penting dalam pelestarian budaya gamelan selonding [3].

Namun saat ini, gamelan selonding tidak pernah dilirik sedikit pun oleh generasi muda untuk memukul bilah-bilahnya. Pemukul selonding yang sudah berusia lanjut seakan tak berdaya untuk menarik para pemudanya untuk menggantikan dirinya, karena generasi penerus lebih senang hidup mengikuti gaya hidup modern atau yang tertarik lebih senang menggebrak drum dan memetik dawai gitar yang lagi populer [4], yang dikuatkan dengan hasil wawancara dengan bapak I Made Pasca Wirsutha, beliau merupakan praktisi gamelan selonding, menurut beliau kebanyakan masyarakat Bali hanya mengetahui gamelan gong kebyar daripada gamelan selonding. Hanya beberapa orang yang mengetahui gamelan selonding, karena untuk buku atau pengetahuan tentang gamelan selonding memang sedikit. Kajian mengenai gamelan selonding saat ini masih terhitung sedikit dibandingkan dengan kajian mengenai gamelan gambang (yang samasama merupakan gamelan tua atau wayah) ataupun seni karawitan lainnya dan menyebabkan generasi muda di Bali kurang mengenal gamelan selonding. Hal ini juga dikuatkan dengan angket pengetahuan gamelan selonding yang disebar di masyarakat, dari 42 orang responden $88,1 \%$ tidak pernah memainkan gamelan selonding.

Salah satu cara agar generasi muda tertarik melestarikan gamelan selonding adalah dibuatkan sebuah game. Menurut Felicia (2011) "dibandingkan dengan metode tradisional, pembelajaran menggunakan game tidak hanya dapat memberikan motivasi, tetapi juga membuat anak belajar dengan bermain dan dapat meningkatkan keterampilan yang masih sulit dikembangkan dalam metode tradisional". Menurut Virvou (2005) "teknologi game dapat memotivasi pembelajaran dan melibatkan pemain, sehingga proses pembelajaran lebih menyenangkan". Game bukan hanya sebagai media hiburan melainkan terdapat nilai pendidikan yang bisa disisipkan di dalamnya. Di sisi lain bahwa bermain game merupakan aktivitas yang tidak asing lagi bagi sebagian besar kalangan generasi muda [5].

Terdapat beberapa penelitian terkait dengan pengembangan aplikasi game gamelan salah satunya dapat dilihat dari penelitian yang dilakukan I Kadek Yostab Mariyantoni, aplikasi Augmented Reality Book pengenalan perangkat gamelan Bali yang mampu melakukan pelacakan penanda sehingga dapat menampilkan objek 3 dimensi gamelan Bali dan suara narasi penjelasan serta suara yang dapat dihasilkan dari perangkat gamelan yang ditampilka [6]. Penelitian yang sejenis juga pernah dikembangkan oleh I Putu Nata Susila pada tahun 2015 yang berjudul Pengembangan Aplikasi Gamelan Selonding Berbasis Android. Pada aplikasi tersebut pemain hanya bisa merasakan dan bermain menggunakan jari tangan saja, sehingga pemain belum benar-benar merasakan bagaimana bermain gamelan selonding secara nyata [7]. Penelitian selanjutnya tentang pengembangan aplikasi gamelan juga dikembangkan oleh eka udiyana pada tahun 2015 dengan mengembangkan Aplikasi Gamelan Angklung Bali Berbasis Android. Aplikasi ini mampu memainkan Gamelan Angklung pada smartphone android. Namun aplikasi ini tidak bisa membuat pengguna berinteraksi langsung memainkan gamelan karena tampilannya dalam 2 dimensi saja [8].

Berdasarkan beberapa penelitian terkait yang sudah dipaparkan diatas, sudah banyak mengembangkan aplikasi mengenai gamelan bali, namun belum ada yang mengembangkan dengan teknologi virtual reality. Peneliti terarik mengembangkan aplikasi Game Selonding berbasis virual reality. Keunggulan virtual reality, pengguna dapat berinterksi langsung dengan objek 3D yang disimulasikan pada komputer. 


\section{METODE}

Pengembangan Game Gamelan Selonding Bali Berbasis Virtual Reality ini menggunakan jenis penelitian Pengembangan atau Research and Development (R\&D) yakni metode penelitian yang digunakan untuk menghasilkan produk tertentu, dan menguji kefektifan produk tersebut [9]. Pengembangan ini menggunakan model ADDIE yang terdiri dari lima tahapan yaitu Analysis (Analisis), Design (Perancangan), Development (Pengembangan), Implementation (Implementasi) dan Evaluation (Evaluasi).

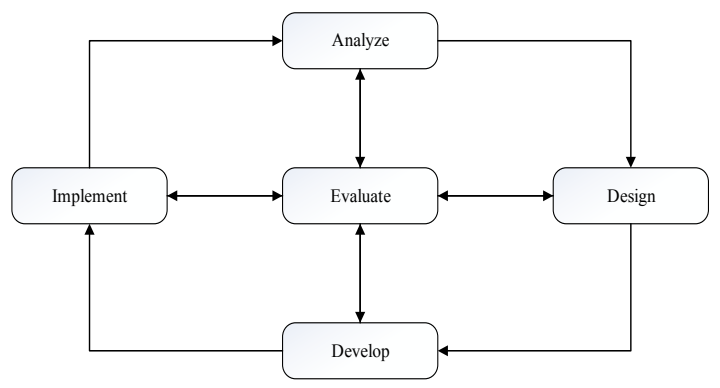

Gambar 1. Tahap alam model ADDIE (sumber: (Tegeh \& Kirna, 2009))

\section{HASIL DAN PEMBAHASAN}

\section{a. Hasil Tahap Anaysis}

Hasil pada tahap ini adalah informasi secara lengkap, yang nantinya harus dipenuhi oleh aplikasi yang dikembangkan. Adapun kebutuhan fungsional dan nonfungsional aplikasi dapat dilihat pada tabel 1 dan Tabel 2.

Tabel 1. Kebutuhan Fungsional

\begin{tabular}{ll}
\hline Kode & \multicolumn{1}{c}{ Deskripsi } \\
\hline KF-01 & $\begin{array}{l}\text { Aplikasi mampu menampilkan main menu (menu } \\
\text { utama) sebelum menuju ke permainan. Adapun } \\
\text { bagian dari main menu, yaitu Mulai, Petunjuk, } \\
\text { Tentang Pengembang, Peraturan dan Keluar. }\end{array}$ \\
KF-02 & $\begin{array}{l}\text { Aplikasi mampu menampilkan pilihan mode yaitu } \\
\text { mode bermain bebas dan mode bermain dengan lagu }\end{array}$ \\
KF-03 & $\begin{array}{l}\text { Aplikasi mampu menampilkan pilihan instrumen, } \\
\text { yaitu adalah Peanem, Petuduh, Nyongnyong Ageng, }\end{array}$ \\
& $\begin{array}{l}\text { Nyongnyong Alit, Gong, Kempur dan Kecek. } \\
\text { KF-04 } \\
\text { Aplikasi mampu memulai permainan baru dan } \\
\text { menampilkan game utama, yaitu memainkan } \\
\text { Gamelan Selonding Bali berdasarkan ritme dari lagu. }\end{array}$
\end{tabular}

KF-05 Aplikasi mampu menampilkan skor saat permainan berlangsung

\begin{tabular}{ll}
\hline Kode & \multicolumn{1}{c}{ Deskripsi } \\
\hline KF-06 & $\begin{array}{l}\text { Aplikasi mampu } \\
\text { permainan selesai }\end{array}$ \\
KF-07 & Aplikasi mampu mengatur volume dari aplikasi \\
KF-08 & $\begin{array}{l}\text { Aplikasi mampu menampilkan informasi tentang } \\
\text { aplikasi dan identitas pengembang dengan menekan } \\
\text { tombol Tentang Pengembang }\end{array}$ \\
KF-09 & $\begin{array}{l}\text { Aplikasi mampu menampilkan perintah keluar dari } \\
\text { aplikasi }\end{array}$
\end{tabular}

\section{b. Hasil Tahap Design}

1. Use Case Diagram

Use case diagram menggambarkan fungsionalitas yang diharapkan dari sebuah sistem. Adapun use case Diagram Pengembangan Game Gamelan Selonding Bali Berbasis Virtual Reality dapat dilihat pada gambar berikut.

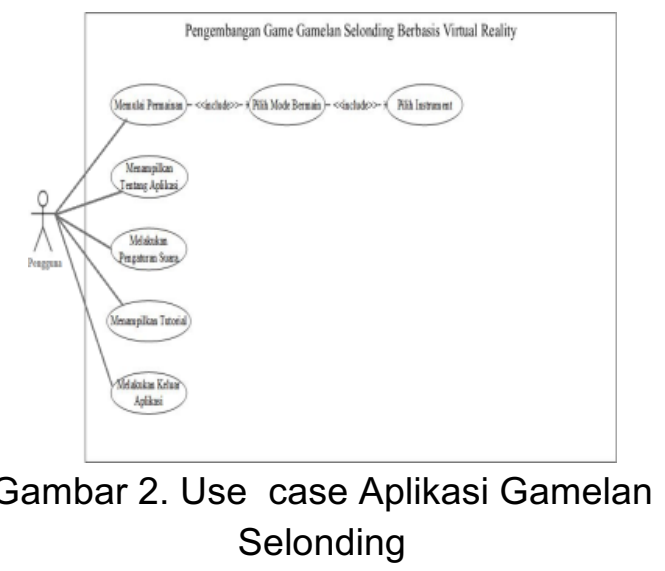

\section{Activity Diagram}

Activity diagram menggambarkan berbagai alir aktivitas dalam sistem yang sedang dirancang, bagaimana masingmasing alir berawal, decision yang mungkin terjadi, dan bagaimana mereka berakhir.

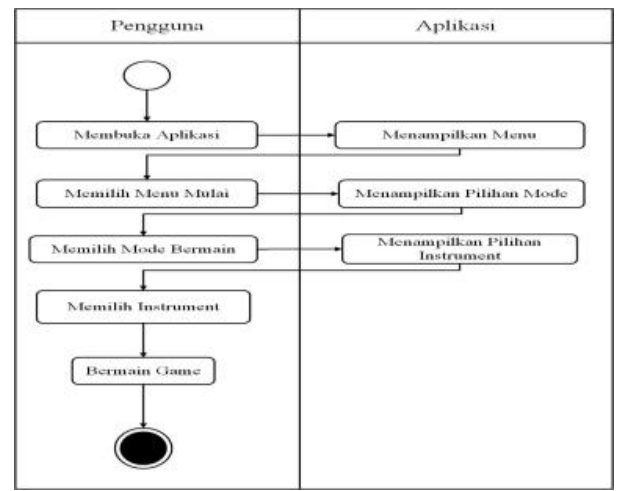

Gambar 3. Use Case memulai permainan

Jurnal Sains dan Teknologi | 67 
Alur dari memulai permainan yaitu, pertama pengguna membuka aplikasi, maka aplikasi akan menampilkan pilihan menu utama. Selanjutnya pengguna memilih menu Mulai, maka aplikasi akan menampilkan menu Mode Permainan. Kemudian pengguna memilih Mode Permainan yang diinginkan, setelah memilih aplikasi akan menampilkan pilihan instrumen. Setelah pengguna memilih instrumen yang akan dimainkan, aplikasi akan menampilkan instrumen tersebut dan selanjutnya pengguna bisa bermain permainan.

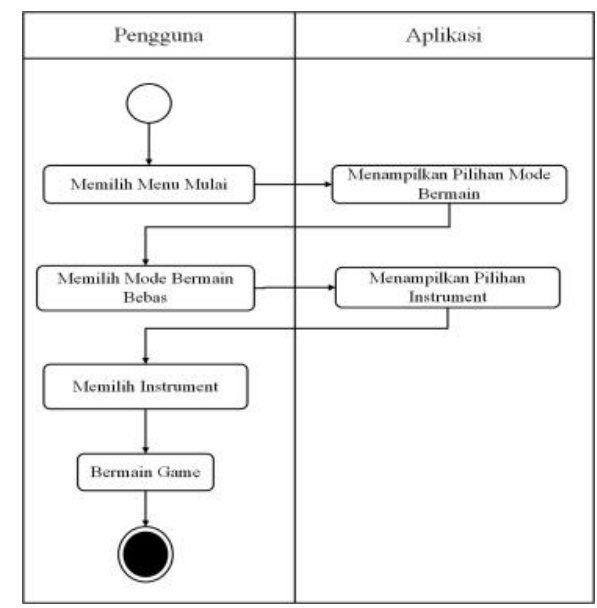

Gambar 4. Activity Diagram Mode Bermain Bebas

Pertama pengguna memilih menu Mulai, kemudian aplikasi akan menampilkan pilihan mode bermain. Selanjutnya pengguna memilih mode Bermain Bebas, dan aplikasi akan menampilkan pilihan instrumen. Kemudian pengguna memilih instrumen dan aplikasi akan menampilkan instrumen tersebut. Selanjutnya pengguna memainkan instrumen yang dipilih. Pengguna dapat bermain.

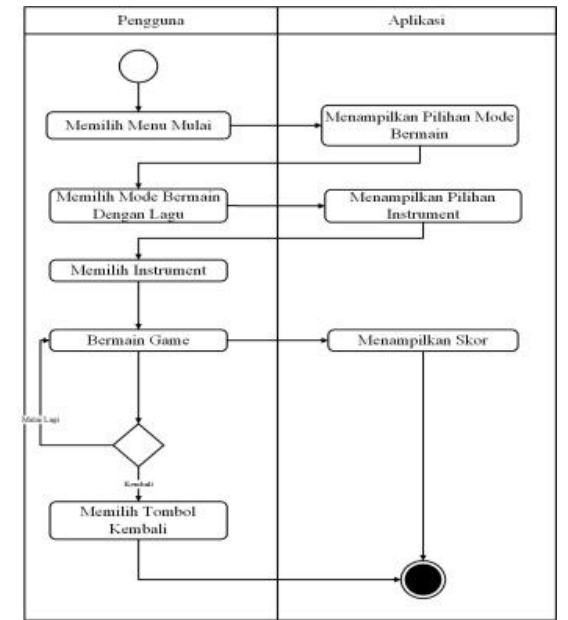

Gambar 5. Activity diagram mode bermain dengan lagu

Pertama pengguna memilih menu Mulai, kemudian aplikasi akan menampilkan pilihan mode bermain. Selanjutnya pengguna memilih mode Bermain Dengan Lagu, dan aplikasi mulai memutar lagu. Selanjutnya pengguna memainkan instrumen dan aplikasi menampilkan skor yang diperoleh pengguna. Setelah permainan berakhir aplikasi menampilkan pilihan mulai permainan lagi atau tidak. Jika pengguna memilih icon ulang, maka aplikasi mulai memutar lagu. Jika pengguna memilih icon menu utama, maka pengguna memilih tombol kembali dan aplikasi menampilkan menu utama.

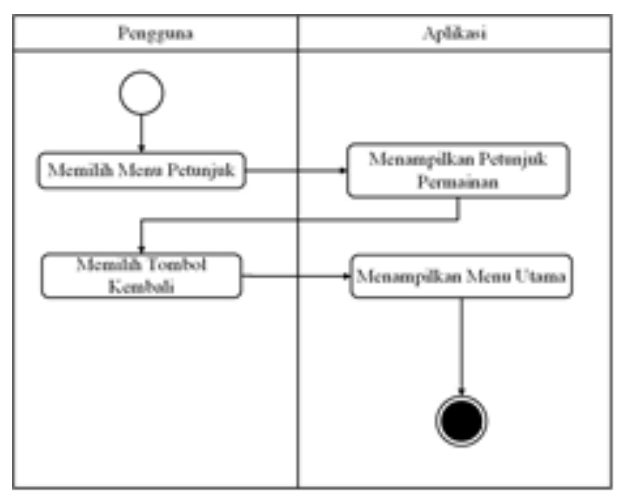

Gambar 6. Activity diagram petunjuk

Pertama pengguna memilih menu Petunjuk, kemudian aplikasi menampilkan petunjuk permainan. Setelah selesai Jurnal Sains dan Teknologi | 68 
pengguna memilih tombol kembali, selanjutnya aplikasi menampilkan Menu Utama.

\section{c. Hasil Tahap Development}

Pada tahap development peneliti mengembangkan aplikasi dengan aplikasi blender untuk pembuatan objek 3d gamelan dan aplikasi unity untuk pembuatan game engine gamelan slonding. Hasil aplikasi gamelan selonding, yang dapat berjalan pada perangkat komputer, dibantu dengan perangkat HTC VIVE.

\section{Hasil Pengembangan Objek 3D}
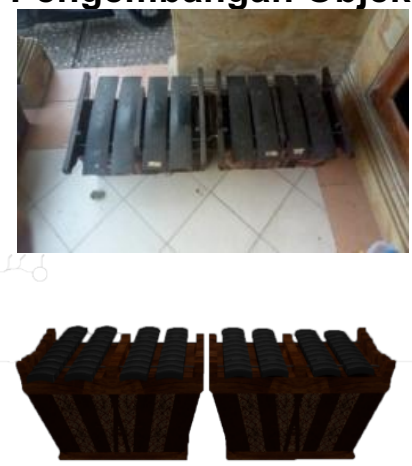

(a)

(b)

Gambar 7. (a) Objek Asli Instrumen Gong, (b) Objek 3D instrumen Gong

Gong terdiri dari 2 tungguh, (besar dan kecil) berdaun 8 bilah. Berfungsi sebagai Jegog. Titilaras gong yaitu : Ding, Dong, Dang, Deng, Dung, Dang, Dong, Ding.

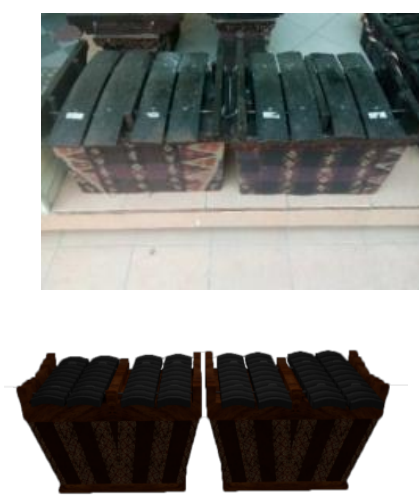

(a)

(b)

Gambar 8. (a) Objek Asli Instrumen Kempur, (b) Objek 3D instrumen Kempur
Kempur terdiri dari 2 tungguh, (besar dan kecil) berdaun 8 bilah. Berfungsi sebagai Jublag. Titilaras kempur yaitu : Ding, Dong, Dang, Deng, Dung, Dang, Dong, Ding.
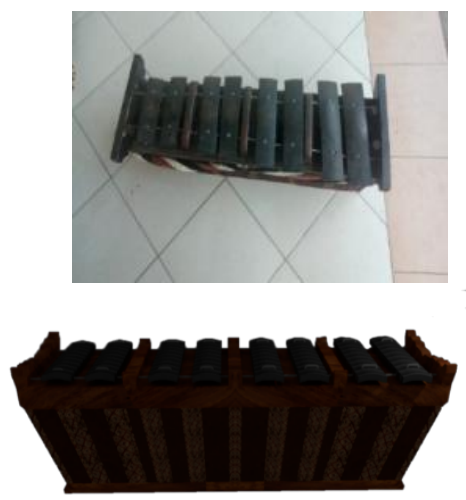

(a)

(b)

Gambar 9. (a) Objek Asli Instrumen Nyongnyong Ageng, (b) Objek 3D instrumen Nyongnyong Ageng

Nyongnyong Ageng terdiri dari 1 tungguh, berdaun 8 bilah. Berfungsi sebagai Gangsa. Titilaras Nyongnyong Ageng yaitu : Ding, Dong, Dang, Deng, Dung, Dang, Dong, Ding.
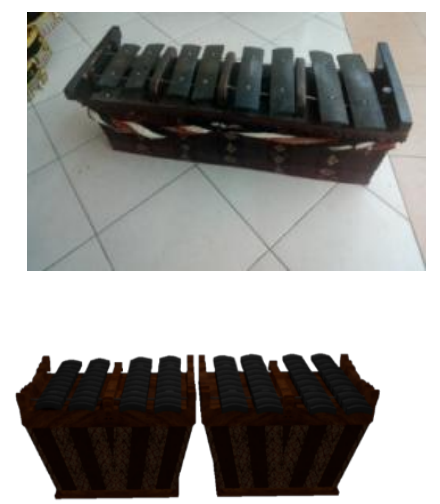

(a) Gambar 11. (a) Objek Asli Instrumen Peanem Petuduh, (b) Objek 3D instrumen Peanem Petuduh

Instrumen Peanem Petuduh terdiri dari 2 tungguh, (peanem dan petuduh) berdaun 8 bilah. Berfungsi sebagai Melodi. Titilaras peanem dan petuduh yaitu : Ding, Dong, Dang, Deng, Dung, Dang, Dong, Ding.

Jurnal Sains dan Teknologi | 69 


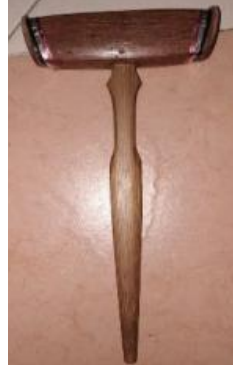

(a)

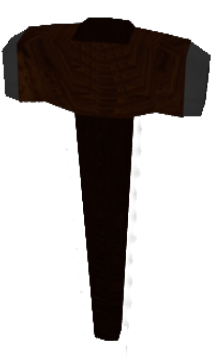

(b)
Gambar 12. (a) Objek Asli Panggul NyongNyong Ageng, Alit dan Peanem Petuduh, (b) Objek 3D Panggul NyongNyong Ageng, Alit dan Peanem Petuduh

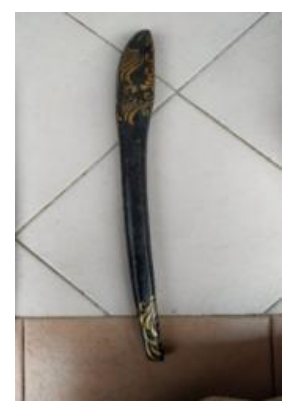

(a)

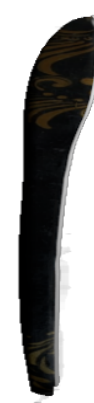

(b)
Gambar 13. (a) Objek Asli Panggul Gong dan Kempur , (b) Objek 3D Panggul Gong dan Kempur

\section{Hasil Pengembangan Aplikasi}

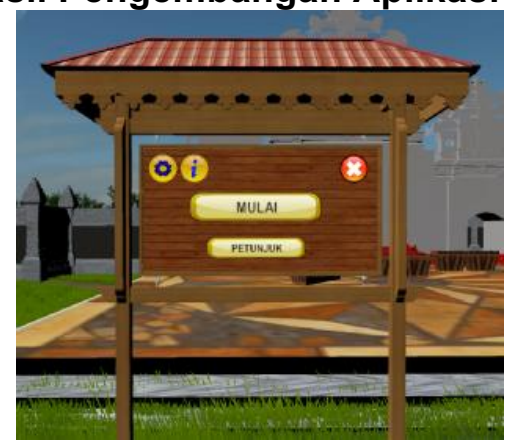

Gambar 14. Tampilan menu aplikasi

Pada menu aplikasi, terdapat tombol mulai, petunjuk, tentang, pengatauran dan keluar. Untuk memulai game, pengguna dapat memilih menu mulai.

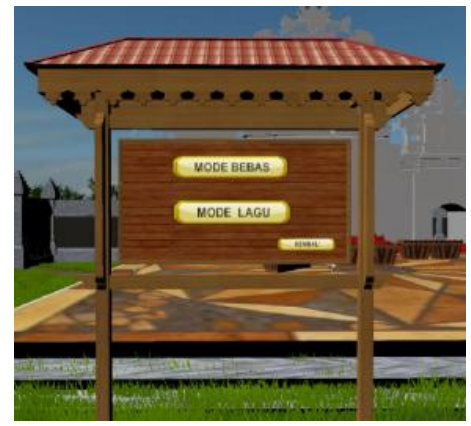

Gambar 15. Tampilan mode game

Tampilan Gambar 15 adalah mode game. Setelah pengguna sebelumnya sudah memilih menu mulai, akan tampil mode game.

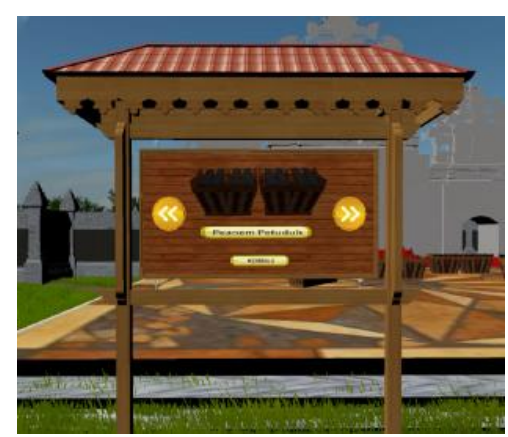

Gambar 16. Tampilan mode game bermain bebas

Pada tampilan Gambar 16, pengguna dapat memilih jenis instrumen yang ingin dimankan. Pada mode ini, pengguna bebas meminkan intrumen,tanpa ada ikatan lagu yang harus diikuti.

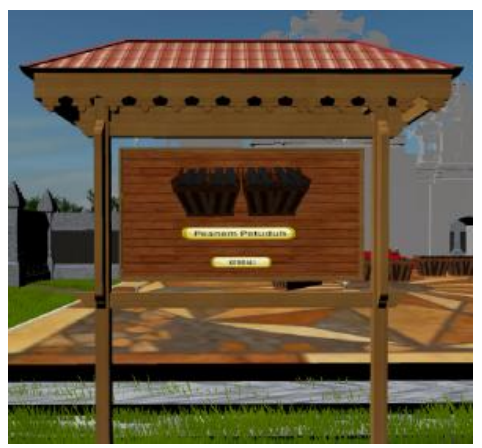

Gambar 17. Tampilan mode game bermain dengan lagu

Pada mode game bermain dengan lagu, pengguna memulai game dengan mengklik gambar instrumen pada aplikasi. Dalam bermain, pengguna harus mengikuti notenote yang terdapat pada aplikasi.

Jurnal Sains dan Teknologi | 70 


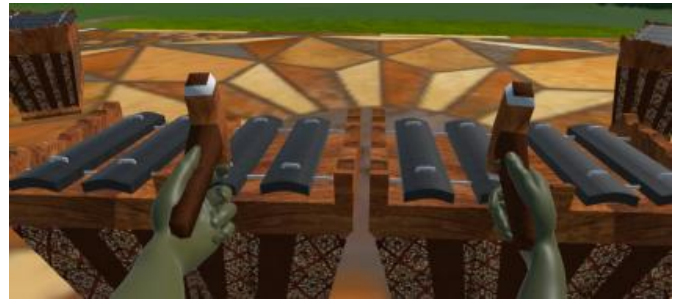

Gambar 18. Tampilan bermain bebas pada aplikasi

Tampilan Gambar 18 adalah mode game bermain bebas. Mode bermain bebas yaitu pengguna memainkan Gamelan Selonding tanpa bantuan musik atau tabuh. Pengguna akan memilih instrumen terlebih dahulu sebelum mulai ke permainan. Pengguna akan memainkan sendiri instrumen yang dipilih dan setelah memukul pemain dapat nekep atau menahan daun gamelan untuk menghentikan resonansi bunyi atau gema. memilih instrumen terlebih dahulu sebelum mulai ke permainan. Pengguna akan memainkan sendiri instrumen yang dipilih dan setelah memukul pemain dapat nekep atau menahan daun gamelan untuk menghentikan resonansi bunyi atau gema.

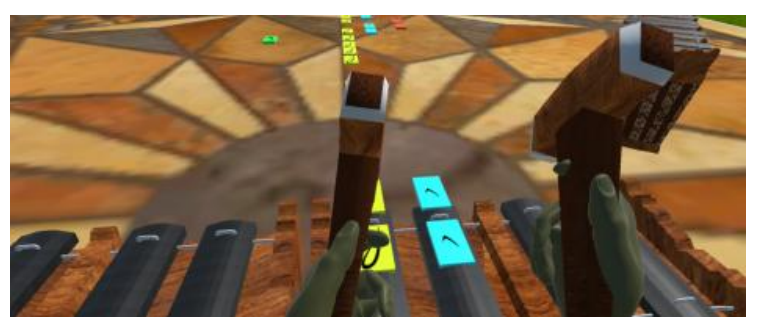

Gambar 19. Tampilan bermain dengan lagu pada aplikasi

Mode bermain lagu yaitu pengguna akan memainkan Gamelan Selonding dengan diiringi lagu atau tabuh. Mode bermain dengan lagu ini pengguna akan diberikan tantangan yaitu memukul notenote yang berjalan.

\section{d. Hasil Tahap Implementasi}

Untuk dapat diimplementasikan, maka perangkat keras baik itu perangkat keras PC dan perangkat keras HTC VIVE harus memenuhi beberapa spesifikasi seperti di bawah ini.
1. Processor
: AMD Ryzen 7 1700X
8-Core $3,4 \mathrm{GHz}$

2. Sistem Operasi : Windows 10 Pro 64bit

3. Memori/RAM : $16 \mathrm{~GB}$

4. VGA : NVIDIA GeForce GTX $1050 \mathrm{Ti}$

5. Storage Device : $1 \mathrm{~TB}$

\section{e. Hasil Tahap Evaluasi}

Pengujian yang pertama yaitu pengujian black box. Pengujian black box dilakukan untuk menguji kebenaran proses dan menguji penggunaan aplikasi. Uji Blackbox pada penelitian ini dilakukan pada 5 orang responden Berdasarkan hasil pengujian pada kasus uji kebenaran proses, bahwa semua proses game dijalankan sampai dengan selesai berfungsi dengan baik.

Tahap evaluasi yang peneliti lakukan selanjutnya untuk mengevaluasi hasil tahap desain ini adalah evaluasi ahli isi. Evaluasi ahli isi ini memfokuskan penilaian pada isi materi dari aplikasi, pemakaian kata dan bahasa, dan pembelajaran. Kriteria yang didapat dalam pengujian ahli isi adalah sangat sesuai dengan nilai $100 \%$.

Evaluasi pada tahap perancangan ini lebih difokuskan pada evaluasi rancangan Visual Design, Audio dan Interface. Rancangan antarmuka dievaluasi oleh ahli media. Hasil untuk uji ahli media berada dalam kriteria sangat sesuai, dengan artinya aplikasi Pengembangan Game Gamelan Selonding masuk kategori sangat baik. Dari hasil yang didapatkan dari pengujian dapat disimpulkan bahwa game Gamelan Selonding Bali Berbasis Virtusl Reality sudah layak untuk melakukan uji responden,

Uji responden dilakukan oleh 20 orang. Analisis untuk uji respons pengguna berada dalam kriteria sangat sesuai, dengan persentase $88,5 \%$.

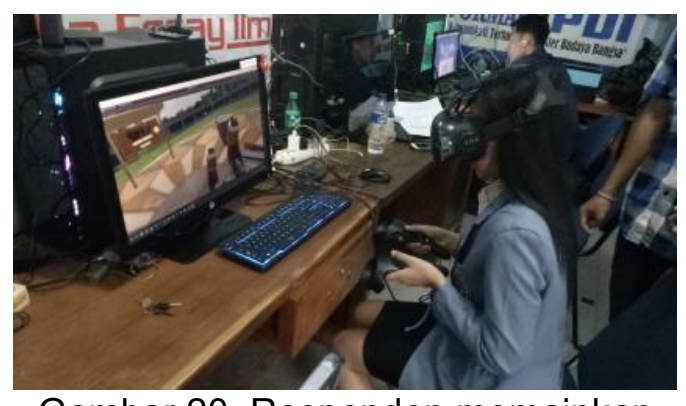

Gambar 20. Responden memainkan Game Gamelan Selonding

Jurnal Sains dan Teknologi | 71 


\section{SIMPULAN}

$\begin{array}{ccc}\text { Pengembangan Game Gamelan } & \text { Game } \\ \text { Selonding Berbasis Virtual Reality }\end{array}$ dikembangkan dengan menggunakan aplikasi Unity 3D, Blender dan audacity. Unity 3D digunakan untuk membuat aplikasi berbasis Virtual Reality, Blender digunakan untuk membuat objek 3D, icon dan gambar latar dan Audacity digunakan untuk mengedit suara atau nada pada gamelan selonding. Setelah pengembangan dilakukan lima pengujian terhadap aplikasi Pengembangan Game Gamelan Selonding Berbasis Virtual Reality, blackbox, whitebox, uji ahli media, uji ahli isi dan uji responden. Dari hasil uji responden pada Pengembangan Game Gamelan Selonding Berbasis Virtual Reality terhadap 20 masyarakat didapatkan hasil $88.5 \%$ yang artinya aplikasi masuk kategori sangat baik.

\section{DAFTAR PUSTAKA}

[1] P. Soeriadiredja, "Fenomena kesenian dalam studi antropologi," pp. 0-38, 2016.

[2] I. W. Aryasa et al., Pengetahuan Karawitan Bali. Denpasar: Departemen Pendidikan Dan Kebudayaan Bali, 1985.

[3] N. P. D. P. Ganeshwari, A. A. N. A. Kumbara, and I. N. Suarsana, "Eksistensi Gamelan Selonding di Desa Bungaya ,"J.

Humanis, Fak. Ilmu Budaya Unud, vol. 18, no. 2, pp. 56-63, 2017.

[4] I. W. E. Suputra, "Filosofi Selonding Dalam Tatwa Hindu," pp. 1-5, 2011.

[5] B. Pane, X. Najoan, and S. Paturusi, "Rancang Bangun Aplikasi Game Edukasi Ragam Budaya Indonesia," EJournal, vol. 12, no. 1, 2017.

[6] I. K. Y. Mariyantoni and P. N. Crisnapati, "Augmented Reality Book Pengenalan Perangkat Gamelan Bali," J. Nas. Pendidik. Tek. Inform., vol. 3, no. 1, pp. 21-28, 2014.

[7] I. P. N. Susila, I. G. M. Darmawiguna, and I. M. G. Sunarya, "PENGEMBANGAN APLIKASI GAMELAN SELONDING BERBASIS ANDROID," Karmapati, vol. 4, no. 2, pp. 82-91, 2014.

[8] I. G. E. Udiyana, I. G. M. Darmawiguna, and I. M. G. Sunarya, "Pengembangan Aplikasi Gamelan Angklung Bali
Berbasis Android," Karmapati, vol. 4, no. 4, pp. 1-9, 2015.

[9] M. A. Pranata, G. S. Santyadiputra, and I. G. P. Sindu, "Game Balinese Fruit Shooter Berbasis Virtual Reality Sebagai Media Pembelajaran Di Taman KanakKanak," Edutech, vol. 16, no. 3, pp. 305324, 2017. 